\title{
Micro- and Meso-Scale Factors Affect the Restoration of Atlantic Forest
}

\author{
Érico E. Kauano ${ }^{1,3}$, Fernanda C. G. Cardoso ${ }^{1}$, José Marcelo D. Torezan² \& \\ Marcia C. M. Marques ${ }^{1 *}$
}

${ }^{1}$ Laboratório de Ecologia Vegetal, Departamento de Botânica, Setor de Ciências Agrárias - SCB, Universidade Federal
do Paraná - UFPR, Curitiba, PR, Brazil
${ }^{2}$ Laboratório de Biodiversidade e Restauração de Ecossistemas, Departamento de Biologia Animal e Vegetal, Centro de
Ciências Biológicas - CCB, Universidade Estadual de Londrina - UEL, Londrina, PR, Brazil
${ }^{3}$ Instituto Chico Mendes de Conservação da Biodiversidade - ICMBio, Floresta Nacional do Amapá, Macapá, AP, Brazil

\begin{abstract}
Ecological restoration is potentially affected by factors acting at both micro- (characteristics of the site for seedling establishment) and meso-scales (landscape features). We evaluated areas undergoing restoration to define the relative importance of some micro-scale factors (soil type, restoration strategy, pasture type) and macro-scale factors (proportion of old-growth forest, immature forest, degraded and humid areas, and the nearest-neighbor distance) at determining forest structure (tree abundance, basal area and species richness) of young (3-11 years) restoration areas. We found that the areas under restoration have higher tree species richness and abundance if old-growth forests are present within distances up to $200 \mathrm{~m}$. We also found that the use of non-invasive fodder grass species in the pasture prior to restoration resulted in higher abundance and basal area of native trees in restoration sites; other factors were less important. These results point to the importance of certain landscape features for the success of restoration, and that the presence of preserved forests nearby is a key factor to be considered when planning recovery of tree species diversity in forest restoration.
\end{abstract}

Key words: Nearest-Neighbor Distance, Scale Effect, Landscape Structure, Tropical Forest, Akaike Information Criterion.

\section{Introduction}

Ecological restoration is an important activity to return ecosystem function and biological diversity to fragmented landscapes (Huxel \& Hastings 1999; Fahrig 2003). By connecting fragments, restoration practices increase the propagule flux and animal movement, and reduce the effects of genetic drift and local extinctions (Bell et al. 1997). However, the efficiency of restoration in biodiversity conservation is potentially affected by factors acting in both micro- and meso-scales. For example, while the local conditions (soil characteristics, restoration strategy, etc.) for seedling survival and growth are a first step for the establishment of the restored ecosystem, the landscape characteristics (presence of propagule sources, type of matrix, etc.) are important for determining if areas undergoing restoration will be able to follow the expected successional trajectory. Thus, assessing the proportional role of local

\footnotetext{
*Send correspondence to: Marcia C. M. Marques

Departamento de Botânica, Setor de Ciências Agrárias - SCB, Universidade Federal do Paraná - UFPR, CP 19031,

CEP 81531-980, Curitiba, PR, Brazil

E-mail:mmarques@ufpr.br
}

and regional factors is an important issue to assure the effectiveness of restoration for biodiversity conservation.

Soil characteristics and water availability, historical land use, and disturbance regime are important filters to seedling establishment in forests undergoing restoration (Holl et al. 2000; Brudvig 2011). They affect seedling micro-habitat and, consequently, influence plant ability for survival and growth (Holl et al. 2000). In fact, avoiding seedling mortality and improving seedling growth is a key factor for restoration success, since they affect the forest biomass, guarantee the environment for the establishment of arriving species, and ultimately, create conditions for restoring ecosystem functions (Holl et al. 2000).

The quality of the matrix and the patches around the restoration area are key determinants of forest structure and composition. While matrix characteristics are important for animal movement, affecting seed dispersal and predation as well as pollination services and herbivory, patch size and distance are associated with the source of propagules for the restoration areas (Jules \& Shahani 2003). Small 
and disturbed forest fragments are characterized by the dominance of a reduced number of pioneer tree species, or by ruderal and exotic species that are not historically related to the plant community trajectory (Uhl et al. 1998). On the other hand, larger fragments are habitat for non-pioneer tree species that are determinants of the maintenance of regional plant diversity (Turner et al. 2001). The relative abundance of patches, as well as their quality, size, and distance to the restoration area are important factors acting on meso-scales and their estimation is crucial for predicting restoration success.

The Brazilian Atlantic Forest is considered one of the hotspots for global biodiversity conservation (Myers et al. 2000 ), with only $16 \%$ of its original cover still remaining in a highly fragmented landscape (Ribeiro et al. 2009). In this scenario, several restoration projects and experiments aiming to connect remaining fragments have been developed over the years in degraded areas of the coastal region of southeast Brazil (Zamith \& Scarano 2006; Ferretti \& Britez 2006; Bruel et al. 2010). Most of these experiments tested the efficacy of different restoration strategies and methods (for example, direct seeding, seedling plantation, passive restoration, nucleation), but it is still unclear which factors limit the success of restoration. In the present study we evaluated restoration areas of the Atlantic Forest in southern Brazil with the objective of defining the relative importance of meso- (landscape) and micro-scale (site conditions and restoration characteristics) factors that determine the forest structure of restoration areas. The hypothesis tested was that tree abundance, basal area and tree species richness in restoration areas increase when they are close to forest remnants, and in sites with better conditions for seedling establishment (non-invasive grass species, restoration by means of seedling planting, and drained and nutrient-rich soil).

\section{Material and Methods}

\section{Study site}

The study was conducted in the northern coast of the state of Paraná in two protected areas (Rio Cachoeira and Morro da Mina reserves), located in the municipalities of Antonina and Morretes, southern Brazil (Figure 1). This region comprises a forest matrix, with $68 \%$ of the area still occupied by late-successional and old-growth forest (Kauano et al. 2012).
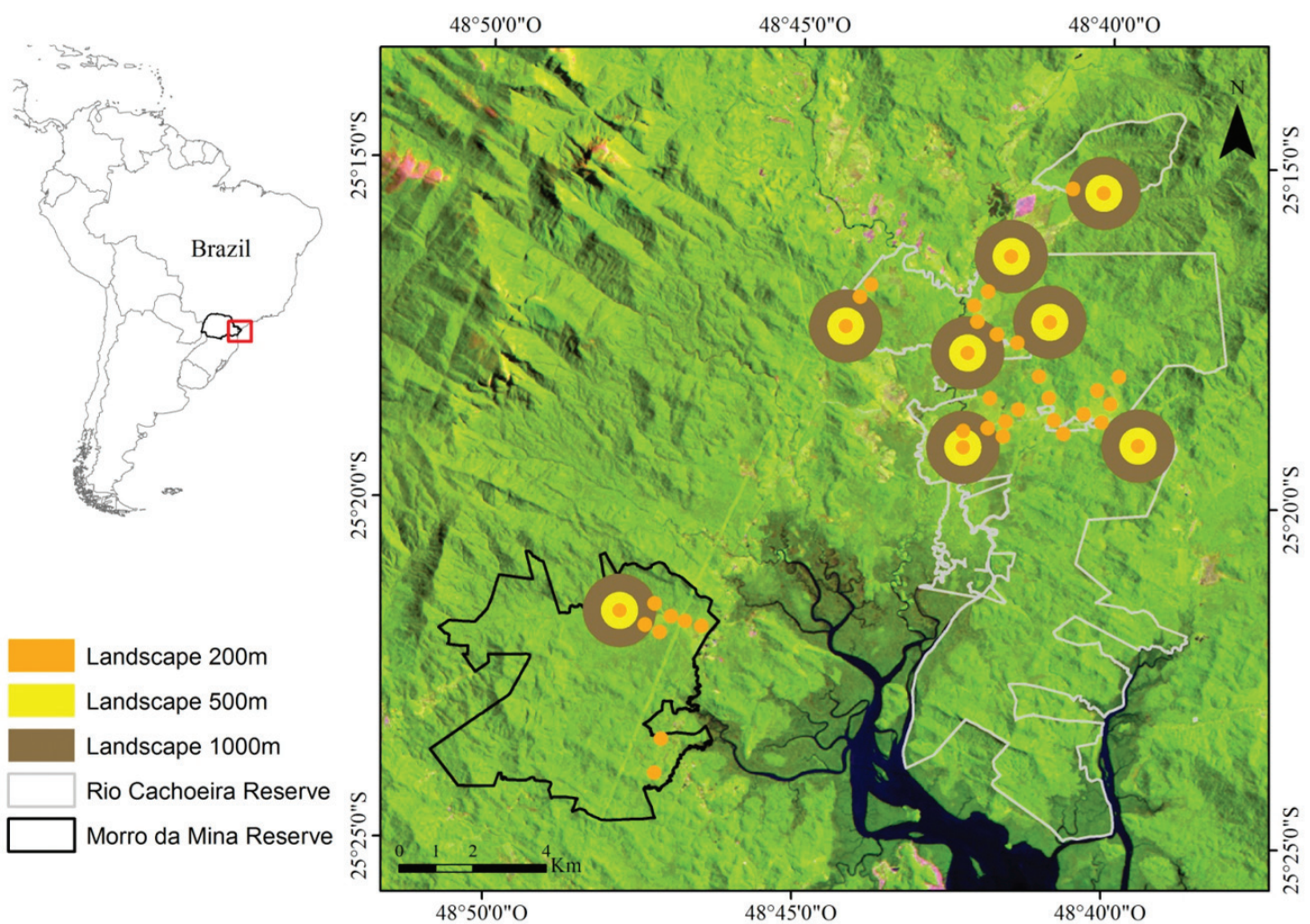

$48^{\circ} 50^{\prime} 0 " \mathrm{O}$

$48^{\circ} 45^{\prime} 0 " \mathrm{O}$

$48^{\circ} 40^{\prime} 0{ }^{\prime \prime} \mathrm{O}$

Figure 1. Studied region in the Rio Cachoeira and Morro da Mina reserves, Paraná State, southern Brazil. Landscape windows of different sizes: 200, 500 and $1000 \mathrm{~m}$ in radius. Composition of RGB (bands 5, 4 and 3) from image mosaics LANDSAT-5-TM from 5th March 2009, orbit/point $220 / 77$ and 220/78. Universal Transverse Mercator Projection, Central Meridian - 51 ${ }^{\circ}$ W.GR, Datum SAD 69. 


\section{Restoration areas}

The reserves and their surroundings have a history of selective logging and deforestation, especially along the plains, driven largely by the conversion of native forest to pastures (mainly Urochloa spp.) for buffalo breeding and agricultural crops (Ferretti \& Britez 2006; Bruel et al. 2010). These areas were used as non-intensive pasture for approximately 30 years. Since 1999, ecological restoration projects have been developed on a total area of 19,000 ha, aiming to restore the biodiversity of the Atlantic Forest and promote carbon sequestration through forest regrowth (Ferretti \& Britez 2006). These areas under restoration are still young ( 3 to 11 years), and vary in their conditions before the restoration occurred (e.g., soil type, grass species used previously in the pastures). They also varied in restoration strategy (active and passive restoration). We selected 39 areas that combine these different variables. The soil types in the restoration areas include Argisol (deep and clay rich soil; present in six restoration areas), Cambisol (well drained soil; $\mathrm{n}=10$ ), Gleysol (humid soils, with water table $\sim 50 \mathrm{~cm} ; \mathrm{n}=17$ ), and Neosol (sandy and organic matter, poor soil; $\mathrm{n}=6$ ).

The sites were covered by three major grass cover types: 1) grass cover dominated by the African grasses Urochloa cf humidicola (Stapf) (Rendle) (Morrone \& Zuloaga) and Urochloa arrecta (Hack. ex T. Durand \& Schinz) Morrone \& Zuloaga), (found in 13 sites). 2) a non-invasive and less aggressive fodder grass species Paspalum species ( $\mathrm{n}=11) .3$ ) a mixture of different grasses including Urochloa spp. and Paspalum sp ( $\mathrm{n}=15)$. Urochloa grasses were introduced for pasture in Brazil, and are highly adaptable to nutrient-poor and high humidity soils.

Two restoration strategies were used: active (seedling plantation) and passive (isolation for forest regeneration). Active restoration was present in 12 areas, where seedlings of 15 fast-growing species were planted in $1.5 \times 2.5$ m grids, resulting in a density of 2,666 seedlings.ha ${ }^{-1}$. Seedlings were produced in a local nursery, and were transplanted when they were 5 -months old ( $15 \mathrm{~cm}$ in height). Soil preparation included roto-tilling; fertilizers were not used. Seedlings were hand-planted in small $(\sim 800 \mathrm{ml})$ hand-made holes. Plotmonitoring process included hand-weeding in the summer of the first year after seedlings were planted. The passive restoration consisted only of pasture abandonment and cattle isolation by fences $(n=27)$. Areas in both restoration strategies were similar prior to the restoration. Details of the study area and restoration characteristics can be found in Ferretti \& Britez (2006) and Bruel et al. (2010).

\section{Definition of landscape and vegetation plots}

We selected 39 circular restoration plots in the reserve maps and assessed the landscape characteristics around them (Figure 1). Each circular plot was $14 \mathrm{~m}$ in radius (615.44 $\mathrm{m}^{2}$ ) and was used to evaluate the plant community in forests under restoration. Circular cutouts of landscape (hereafter, landscape windows) around plots were designed to assess the landscape characteristics (see below). We established 39 circular landscape windows of $200 \mathrm{~m}$ radius each. In eight of these, we also established concentric windows of $500 \mathrm{~m}$ and $1000 \mathrm{~m}$ radius in order to verify if scale affects results (see below). All windows were chosen in order to avoid overlapping between landscape windows of the same radius size (Figure 1 ).

\section{Survey and analysis of vegetation}

In the 39 plots all trees with diameter at breast height $(\mathrm{DBH})>5 \mathrm{~cm}$ were identified and their $\mathrm{DBH}$ measured. We calculated total tree abundance, species richness and basal area for each plot.

\section{Landscape analysis}

We used maps from two reserves (scale 1:25,000) to classify landscape units. The four resulted classes were: 1 ) wetlands (including ponds, swamps and grasslands with fluvial influence), 2) disturbed areas (agriculture, pastures, anthropogenic areas), 3) immature forest (young secondary forest), 4) old growth forest (alluvial, submontane and lowland forests, undisturbed or resulted from a secondary succession with more than 100 years). Each landscape window was then individually analyzed according to the following landscape metrics (McGarigal \& Marks 1995): proportion of land use and land cover classes (four landscape classes) and nearest-neighbor distance (distance from the nearest old-growth forest). Variables were produced with the application Vlate (Lang \& Blaschke 2007) in ArcGIS software.

\section{Analysis}

We analyzed any possible spatial structure in the data using Moran's $I$ test for spatial autocorrelation in the software SAM 4.0 (Rangel et al. 2006). Since Moran's I was not significant in any of the three landscape window sizes, we assumed no spatial structure in our data. Then, we constructed models using the meso-scale (four landscape classes, nearest-neighbor distance) and micro-scale (soil type, pasture type and restoration strategy) as explanatory variables, and tree abundance, species richness and basal area as response variables. We used model selection and multi-model inference approaches to compare the likelihood of different models. Models were compared based on Akaike Information Criterion (AIC) and multi-model inference values based on model averaging were estimate for the relative importance of each explanatory variable. Complete method description is in Supplementary Material ${ }^{\star *}$.

\footnotetext{
${ }^{* *}$ see supplementary material available at abeco.org.br.
} 
After choosing the best explanatory variables, we compared the differences of these variables with linear models (ANOVA and regression).

Effects of landscape scale: Considering that the area of the landscape window affects the inclusion of landscape characteristics, we tested the effects of each landscape variable on the response variables and compared them in windows of $200 \mathrm{~m}, 500 \mathrm{~m}$ and $1000 \mathrm{~m}$ (Figure 1). We did not find any significant pattern among variables and scales; therefore we showed these results only in Supplementary Material.

\section{Results}

The best models selected to describe tree abundance, species richness and basal area include the following explanatory variables: proportion of old-growth forest, disturbed areas, immature forest, restoration strategy and pasture type (Table 1). Proportion of old-growth forest was present in two models (for abundance and species richness) and pasture type also appeared in two models (for abundance and basal area).

According to the model averaging procedure, the proportion of old-growth forest and pasture type (i.e. grass species covering the area prior to restoration) were consistently the explanatory variables that more significantly affected the abundance, species richness and basal area of trees (Table 2). High importance values do not necessarily mean that variables have a good predictive power, but combining this result with the AIC models (Table 1) suggests that the proportion of old-growth forest and pasture type stand out as important factors for restoration success.
Analyzing each variable resulting from the models, we observed that the increased proportion of old-growth forest was positively related to tree abundance and species richness (Figures $2 \mathrm{a}$ and $2 \mathrm{~b}$ ). Restoration areas previously covered with non-invasive grass species had, in average, higher abundance and basal area than areas with a mixture of grass species or with Urochloa spp. (Figures $2 \mathrm{c}$ and 2d). Areas restored using planting seedlings had higher abundance than those restored by passive restoration (Figure 2e). Finally, no significant relationships were found between the proportions of disturbed areas and immature forest, and basal area in these restoration areas (Figures $2 \mathrm{f}$ and $2 \mathrm{~g}$ ).

\section{Discussion}

The study of the relative importance of micro- and meso-scale factors determining the forest structure of the restoration sites of the Atlantic Forest in southern Brazil showed that forests under restoration have higher species richness and abundance if preserved habitat areas (old-growth forests) are present in distances up to $200 \mathrm{~m}$. These results suggest that the presence of preserved forests is a key factor to be considered when planning forest restoration.

Old-growth and mature forests are characterized by a greater variety of habitats for animals and plants (Liebsch et al. 2008; Pardini et al. 2010) and by complex structure and diverse plant communities with higher availability of propagules (Holl et al. 2000), compared to immature or young forests. It is possible that these characteristics strongly affected forest structure in the studied restoration areas, since the proportion of old-growth forest was the most important explanatory variable in most of the models. Old-growth

Table 1. Model selection using Akaike Information Criterion (AIC). The best model consisted of different meso- and micro-scale explanatory variables, affecting tree abundance, species richness and basal area. AIC $w_{\mathrm{i}}=$ Akaike Information Criterion weight.

\begin{tabular}{|c|c|c|c|c|c|}
\hline \multirow{2}{*}{ Response variables } & \multicolumn{2}{|c|}{ Explanatory variables } & \multirow{2}{*}{$\mathbf{R}^{2}$} & \multirow{2}{*}{ AIC } & \multirow{2}{*}{$\operatorname{AIC} w$} \\
\hline & Meso-scale & Micro-scale & & & \\
\hline Abundance & old-growth forest & $\begin{array}{c}\text { restoration strategy, } \\
\text { pasture type }\end{array}$ & 0.47 & 350.5 & 0.07 \\
\hline Species richness & old-growth forest & none & 0.36 & 220.8 & 0.08 \\
\hline Basal area & disturbed areas, immature forest & pasture type & 0.39 & 222.9 & 0.05 \\
\hline
\end{tabular}

Table 2. Multi-model inference showing the importance value of each explanatory variable. Bold: highest importance values for each response variable.

\begin{tabular}{llccc}
\hline \multirow{2}{*}{ Explanatory variables } & \multicolumn{3}{c}{ Response variables } \\
\cline { 3 - 5 } Meso-scale & Abundance & Species richness & Basal area \\
& Wetlands & 0.40 & 0.31 & 0.45 \\
& Disturbed areas & 0.45 & 0.32 & 0.50 \\
& Immature forest & 0.50 & 0.39 & 0.52 \\
& Old-growth forest & $\mathbf{0 . 7 0}$ & $\mathbf{0 . 9 0}$ & 0.67 \\
\multirow{3}{*}{ Micro-scale } & Nearest-neighbor distance & 0.25 & 0.27 & 0.45 \\
& Restoration strategy & 0.53 & 0.22 & 0.22 \\
& Soil type & 0.21 & 0.24 & 0.55 \\
\hline
\end{tabular}


Abundance

(a)

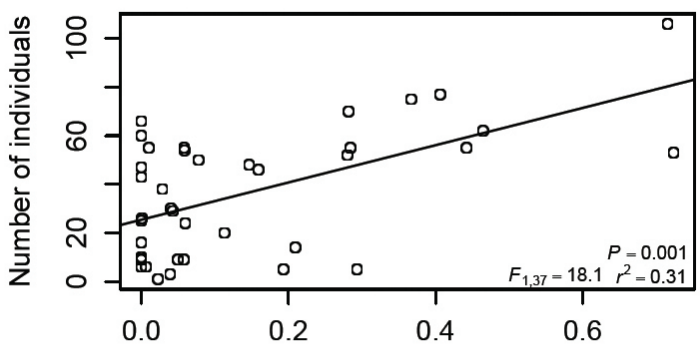

Proportion of old-growth forest

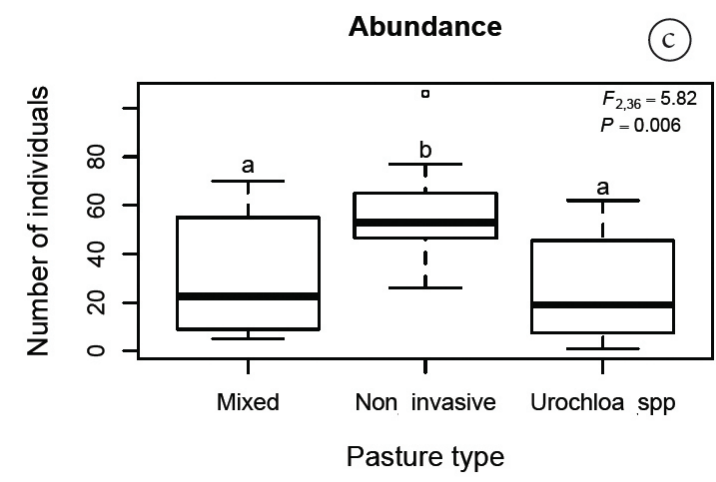

Abundance

(e)

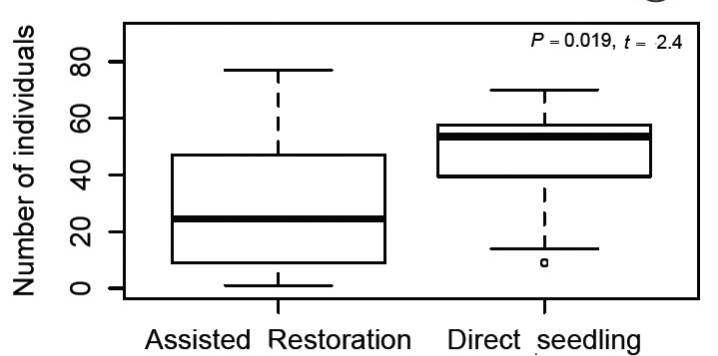

Restoration Strategy

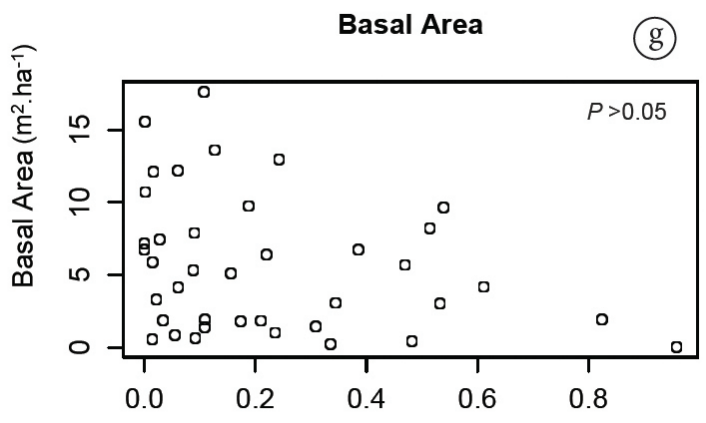

Proportion of immature forest
Species Richness

(b)

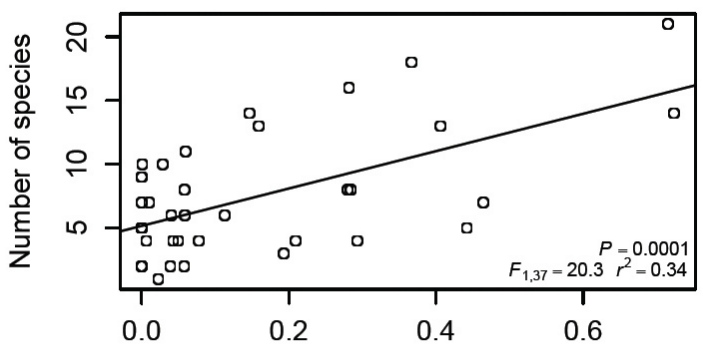

Proportion of old-growth forest

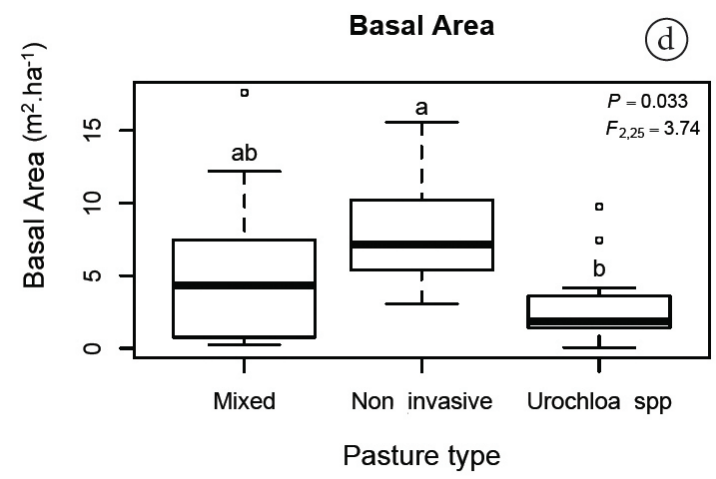

Basal Area

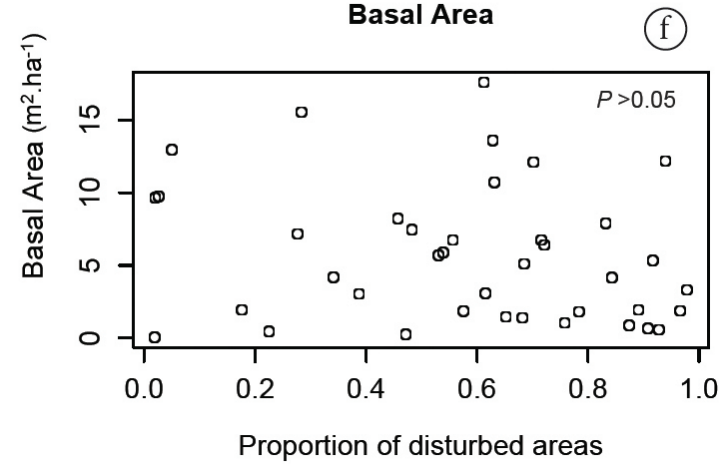

Figure 2. Effects of meso- (proportion of old-growth forest, disturbed areas and immature forest) and micro-scale (pasture type and restoration strategy) variables on the structure of plant communities (abundance, species richness and basal area) in areas undergoing restoration. Only variables selected in the best model of each response variable are presented. One outlier was removed in "d" and one in "e". 
forest affected not only species richness, but also forest abundance and basal area of restored forests. It is relatively well documented that tree species diversity in fragmented forests declines with lower proportions of natural habitats (Bascompte \& Rodriguez 2001), but the positive effects of forested landscapes in forest species richness and structure (abundance and basal area) is possibly new important empirical support for restoration ecology. However, it is important to notice that the studied region is located in a large and well-preserved fragment of Atlantic forest, where the landscape consists of $68 \%$ forested areas (Kauano et al. 2012). The positive effects of surrounding areas on the structure of restored forests are likely to be more evident in highly fragmented landscapes.

Other meso-scale variables were less frequently included in the models: the nearest-neighbor distance and the proportions of wetlands, disturbed areas and immature forests. High distances of a source of propagules are one of the factors affecting negatively ecological succession in restoration areas (Uhl et al. 1988; Galanes \& Thomlinson 2009; see also Pereira et al. 2013 in this issue) and abandoned pastures (Dosch et al. 2007). Also, wet and more disturbed areas limit the plant occurrence and species diversity surrounding the restoration area, possibly affecting the results of restoration (Holl 1999). Nonetheless, our results did not support these previous studies, probably because these landscape features are underrepresented in the region, comparatively to old-growth forests.

From all micro-scale explanatory variables, pasture type and restoration strategy were the most important factors to explain the response variables (abundance, species richness and basal area). The restoration in pastures planted with the non-invasive grass species (possibly Paspalum sp) showed a higher abundance and basal area than pastures where Urochloa spp. (former Brachiaria) or a mixture of grass species were used, possibly because the invasive and fast-growing Urochloa spp. limited seedling establishment. Some species of Urochloa limit tree growth and survival by allelopathy or physical impediment to root growth (Pivello et al. 1999). It is also reported that tree seed germination is limited in pastures with exotic grasses (Florentine \& Westbrooke 2004). Thus, pasture type can strongly influence restoration results and have to be considered in restoration projects.

We found higher tree abundance in restoration using the seedling planting strategy compared to the passive restoration strategy. Considering that seed dispersal is not limited in the region (because of the forested matrix, Kauano et al. (2012)), both planted and naturally regenerated areas have the same probability of propagule arrival, resulting in sites with similar species richness (unpublished data). Nonetheless, by planting seedlings a higher initial stem density is achieved, speeding soil coverage and microclimate improvement. However, passive restoration, which also showed good results in the studied region, can be preferred if budgets are limited.
Surprisingly, soil type was only marginally included in the models. Humid soils (such as Gleysol) can drastically affect tree growth in restoration areas (Cardoso et al. 2012). Well-drained soils (such as Cambisol, Argisol and Neosol) promote a more suitable microsite for seedling growth in the region (Cardoso et al. 2012 and personal observation). Thus, the weak effect of soil types in our models must be interpreted with caution since strong soil effects on restoration were reported elsewhere.

Studies have suggested that the interaction between landscape ecology and restoration ecology are fruitful for both disciplines and may be a necessary approach in the current scenario of fragmentation (Bell et al. 1997; Holl \& Crone 2004). Historically, restorationists were concerned with micro-scale effects on restoration effectiveness, and study designs eclipsed the negative factors acting in the habitat scale. Our results support the vision that meso-scale is important in ecological restoration, which can be more ecologically and economically effective if the landscape is considered in the planning of restoration projects and programs.

\section{Acknowledgements}

We are grateful to Brazilian Research Council (CNPq: 577336/2008-8 and 552608/2010-6) and to the foundation FGB (Fundação Grupo O Boticário), for their financial support; to the non-governmental organization SPVS (Sociedade de Pesquisa em Vida Selvagem e Educação Ambiental) for allowing the study in its reserves and assigning maps and images; to Ricardo Miranda de Britez for his help with images; André A. Padial, Giselda Durigan and Isabela Varassin for their suggestions to the previous version of the manuscript; Danielle Rappaport for language revision. F. C. G. Cardoso received a fellowship from $\mathrm{CNPq}$; M.C.M. Marques and J.M.Torezan received productivity grants from CNPq (grant numbers 304650/2012-9 and 305854/2012-7, respectively).

\section{References}

Bascompte J \& Rodriguez MAÂ, 2001. Habitat patchiness and plant species richness. Ecology Letters, 4:417-420. http:// dx.doi.org/10.1046/j.1461-0248.2001.00242.x

Bell SS, Fonseca MS \& Motten LB, 1997. Linking Restoration and Landscape Ecology. Restoration Ecology, 5:318-323. http://dx.doi.org/10.1046/j.1526-100X.1997.00545.x

Brudvig LA, 2011. The restoration of biodiversity where has research been and where it need to go? American Journal of Botany, 98:1-10. http://dx.doi.org/10.3732/ajb.1000285

Bruel BO, Marques MCM \& Britez RM, 2010. Survival and Growth of Tree Species under Two Direct Seedling Planting Systems. Restoration Ecology, 18: 414-417. http://dx.doi. org/10.1111/j.1526-100X.2009.00634.X

Cardoso FCG et al., 2012. Stem growth and phenology of two tropical trees in contrasting soil conditions. Plant Soil 354:269-281. http://dx.doi.org/10.1007/s11104-011-1063-9 
Dosch JJ, Peterson CJ \& Haines BL, 2007. Seed rain during initial colonization of abandoned pastures in the premontane wet forest zone of southern Costa Rica. Journal of Tropical Ecology, 23:151-159. http://dx.doi.org/10.1017/S0266467406003853

Fahrig L, 2003. Effects of habitat fragmentation on biodiversity. Annual Review of Ecology, Evolution and Systematics, 34:487-515.

Ferretti AR \& Britez RM, 2006. Ecological restoration, carbon sequestration and biodiversity conservation: The experience of the Society for Wildlife Research and Environmental Education (SPVS) in the Atlantic Rain Forest of Southern Brazil. Journal for Nature Conservation, 14:249-259. http:// dx.doi.org/10.1016/j.jnc.2006.04.006

Florentine SK \& Westbrooke ME, 2004. Restoration on abandoned tropical pasturelands do we know enough? Journal for Nature Conservation, 12, 85-94. http://dx.doi. org/10.1016/j.jnc.2003.08.003

Galanes IT \& Thomlinson JR, 2009. Relationships between spatial configuration of tropical forest patches and woody plant diversity in northeastern Puerto Rico. Plant Ecology, 201:101-113. http://dx.doi.org/10.1007/s11258-008-9475-1

Holl KD, 1999. Factors limiting tropical rain forest regeneration in abandoned pastures: seed rain, seed germination, microclimate and soil. Biotropica 31:229-249.

Holl KD \& Crone EE, 2004. Applicability of landscape and island biogeography theory to restoration of riparian understorey plants. Journal of Applied Ecology, 41:922-933. http://dx.doi. org/10.1111/j.0021-8901.2004.00949.x

Holl KD et al., 2000. Tropical montane forest restoration in Costa Rica: overcoming barriers to dispersal and establishment. Restoration Ecology, 8:339-349. http:// dx.doi.org/10.1046/j.1526-100x.2000.80049.x

Huxel GR \& Hastings A, 1999.Habitat loss, fragmentation and restoration. Restoration Ecology, 7:309-315. http://dx.doi. org/10.1046/j.1526-100X.1999.72024.X

Jules ES \& Shahani P, 2003. A broader ecological context to habitat fragmentation: Why matrix habitat is more important than we thought. Journal of Vegetation Science, 14:459-464. http://dx.doi.org/10.1111/j.1654-1103.2003.tb02172.x

Kauano EE et al., 2012. Landscape structure in the northern coast of Paraná state, a hotspot for the Brazilian Atlantic forest conservation. Revista Árvore, 36:961-970.
Lang S \& Blaschke T, 2007. Análise da paisagem com SIG. São Paulo: Oficina de Textos.

Liebsch D, Marques MCM \& Goldenberg R, 2008. How long does the Atlantic Rain Forest take to recover after a disturbance? Changes in species composition and ecological features during secondary succession. Biological Conservation,141:1717-1725. http://dx.doi.org/10.1016/j. biocon.2008.04.013

McGarigal K. \& Marks BJ, 1995. FRAGSTATS: Spatial pattern analysis program for quantifying landscape structure. USDA For. Serv. Gen. Tech. Rep. PNW-351p.

Myers $\mathrm{N}$ et al., 2000. Biodiversity hotspots for conservation priorities. Nature, 403:853-845. http://dx.doi. org/10.1038/35002501

Pardini R et al., 2010. Beyond the Fragmentation Threshold Hypothesis: Regime Shifts in Biodiversity Across Fragmented Landscapes. PLoS ONE, 5. http://dx.doi.org/10.1371/ journal.pone.0013666

Pereira LCSM, Oliveira CCC \& Torezan JMD, 2013. Woody Species Regeneration in Atlantic Forest Restoration Sites Depends on Surrounding Landscape. Natureza \& Consevação, 11:138-144.

Pivello VR, Shida CN \& Meirelles ST, 1999. Alien grasses in Brazilian savannas: a threat to biodiversity. Biodiversity \& Conservation, 8:1281-1294.

Rangel TFLVB, Diniz-Filho JAF \& Bini LM, 2006. Towards an integrated computational tool for spatial analysis in macroecology and biogeography. Global Ecology and Biogeography, 15:321-327.

Ribeiro MC et al., 2009. The Brazilian Atlantic Forest: How much is left, and how is the remaining forest distributed? Implications for conservation. Biological Conservation, 142:1141-1153. http://dx.doi.org/10.1016/j. biocon.2009.02.021

Turner MG, Gardner RH \& O'Neill RV, 2001. Landscape ecology in theory and practice. New York: Springer-Verlag.

Uhl C, Buschbacher R \& Serrão EAS, 1998. Abandoned pastures in eastern Amazonia: I. Patterns of plant succession. Journal of Ecology, 76: 663-681.

Zamith LR \& Scarano FR, 2006. Restoration of a restinga sandy coastal plain in Brazil: survival and growth of planted woody species. Restoration Ecology, 14:87-94. http://dx.doi. org/10.1111/j.1526-100X.2006.00108.x

Received: March 2013

First Decision: July 2013

Accepted: December 2013 